\title{
Severe psoriatic acroosteolysis in the absence of psoriatic arthropathy
}

\author{
R Sakthiswary, ${ }^{1}$ AS Naicker, ${ }^{2} 0$ Htwe, ${ }^{2}$ MS Mohd Shahrir, ${ }^{1}$ SS Sazliyana ${ }^{1}$
}

${ }^{1}$ Department of Medicine, Universiti Kebangsaan Malaysia, Kuala Lumpur, Malaysia;

2Department of Orthopaedics, National University of Malaysia, Kuala Lumpur, Malaysia

Correspondence to Dr Sakthiswary Rajalingham, sakthis5@hotmail.com

\section{DESCRIPTION}

The patient was a 74-year-old gentleman with underlying palmoplantar psoriasis (figure 1). He was electively admitted for left below knee amputation for cutaneous squamous cell carcinoma at his left heel with locoregional spread. He was incidentally found to have symmetrical shortening of his fingers. On further questioning, we discovered that this

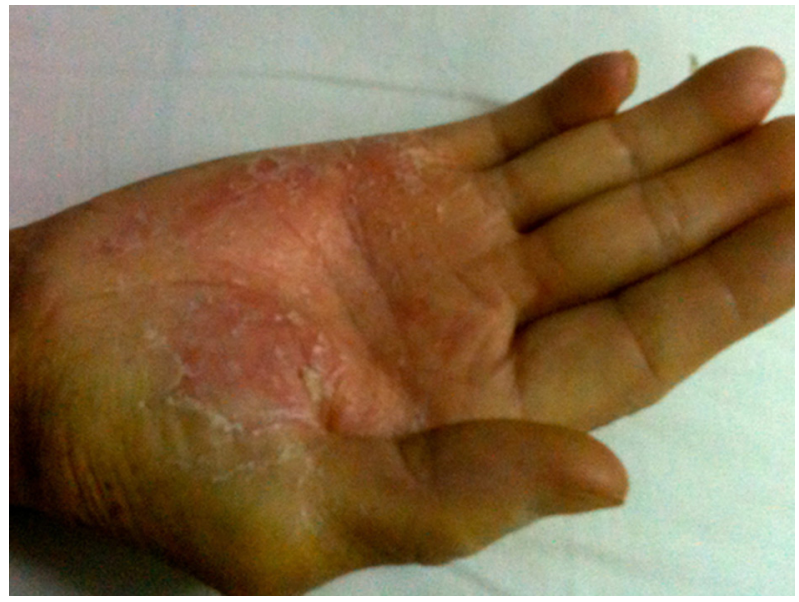

Figure 1 Erythematous, desquamating skin lesion on the palmar surface of the right hand due to psoriasis.

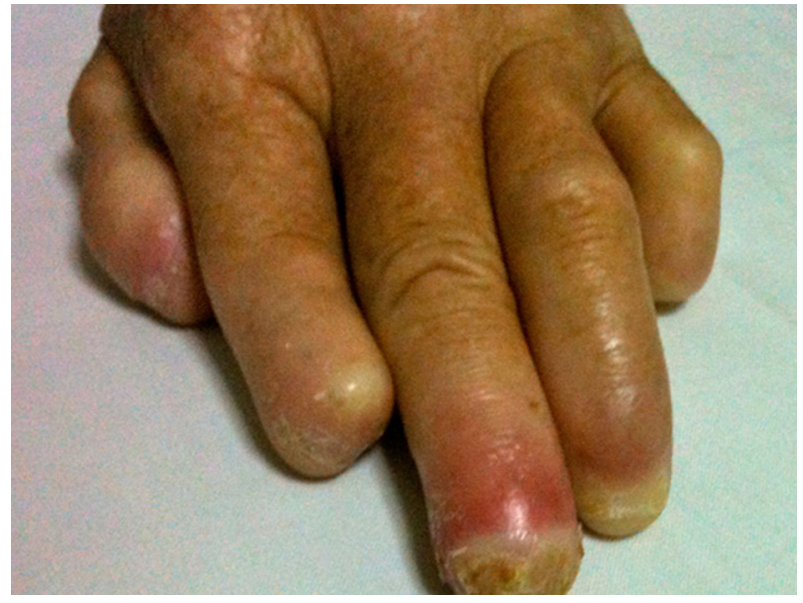

Figure 2 Shortening of fingers of the left hand with loss of nails in most of the digits. had occurred over a period of 5 years. He had no joint pain, symptoms of Raynaud phenomenon or traumatic hand injury. On examination, there was symmetrical shortening of the distal phalanges with loss of nails in most of the digits (figure 2). Connective tissue screening was negative for antinuclear antibodies, rheumatoid factor and anti topoisomerase I. Radiograph of the hands showed terminal resorption of the distal phalanges that is, acroosteolysis. There were no erosions of the articular surfaces (figure 3 ). The radiographs of his feet were normal. Acroosteolysis is a recognised radiological finding in psoriatic arthropathy; which may precede psoriasis by years. ${ }^{1}$ The other wellestablished aetiologies of acroosteolysis are scleroderma, frostbite and hyperparathyroidism. This case highlights the occurrence of psoriatic acroosteolysis in the absence of psoriatic arthropathy. To the best of our knowledge, this is the second reported case of its kind. ${ }^{2}$ In 1959, Buckley et al reported a case of psoriasis with progressive osteolysis following trauma. This was thought to be linked to Koebner phenomenon which is known to occur following physical stimuli. ${ }^{3}$ This case differs from that as there were no identifiable triggers. Till today, the pathogenesis involved in the osteolytic process remains unknown.

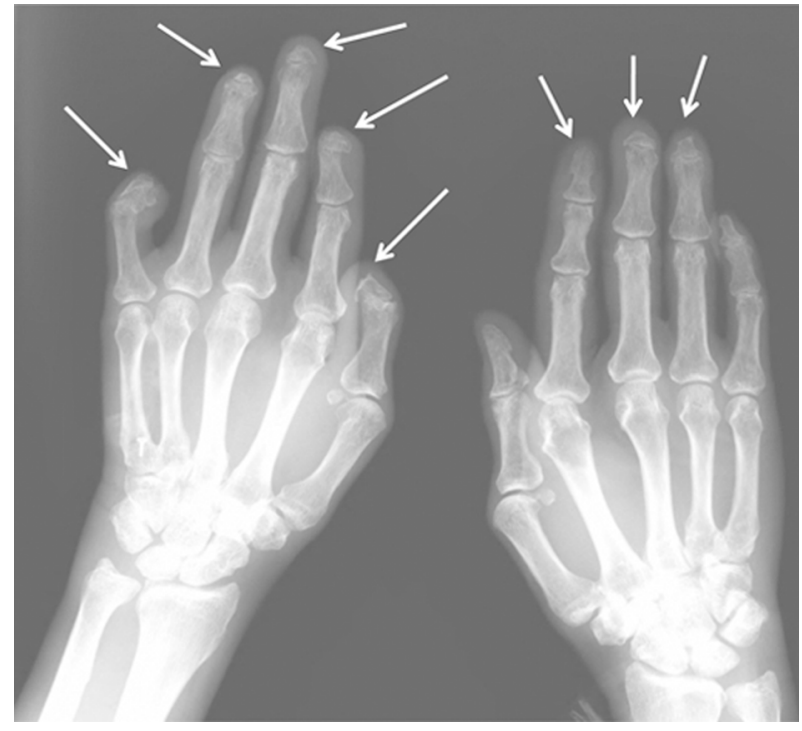

Figure 3 Radiograph of the hands showing terminal resorption of the distal phalanges (acroosteolysis) without any erosion of the articular surfaces. 


\section{BMJ Case Reports}

Competing interests None.

Patient consent Obtained.

\section{REFERENCES}

1. Ory PA, Gladman DD, Mease PJ. Psoriatic arthritis and imaging. Ann Rheum Dis 2005;64 Suppl 2:ii55-7.
2. Miller JL, Soltani K, Tourtellotte CD. Psoriatic acro-osteolysis without arthritis. A case study. J Bone Joint Surg Am 1971;53:371-4.

3. Buckley WR, Raleigh RL. Psoriasis with acro-osteolysis. N Eng/J Med 1959;261:539-41.

This pdf has been created automatically from the final edited text and images.

Copyright 2011 BMJ Publishing Group. All rights reserved. For permission to reuse any of this content visit http://group.bmj.com/group/rights-licensing/permissions.

BMJ Case Report Fellows may re-use this article for personal use and teaching without any further permission.

Please cite this article as follows (you will need to access the article online to obtain the date of publication).

Sakthiswary R, Naicker AS, Htwe 0, Mohd Shahrir MS, Sazliyana SS. Severe psoriatic acroosteolysis in the absence of psoriatic arthropathy. BMJ Case Reports 2011;10.1136/bcr.09.2011.4794, Published XXX

Become a Fellow of BMJ Case Reports today and you can:

- Submit as many cases as you like

- Enjoy fast sympathetic peer review and rapid publication of accepted articles

- Access all the published articles

- Re-use any of the published material for personal use and teaching without further permission

For information on Institutional Fellowships contact consortiasales@bmjgroup.com

Visit casereports.bmj.com for more articles like this and to become a Fellow 